\title{
MARKET PRICE ACCOUNTING AND DEPOSITOR DISCIPLINE IN JAPANESE REGIONAL BANKS
}

\author{
Mark M. Spiegel \\ Federal Reserve Bank of San Francisco \\ and \\ Nobuyoshi Yamori \\ Nagoya University
}

May 10, 2004

Working Paper 2004-27

http://www.frbsf.org/publications/economics/papers/2004/wp04-27bk.pdf

The views in this paper are solely the responsibility of the authors and should not be interpreted as reflecting the views of the Federal Reserve Bank of San Francisco or the Board of Governors of the Federal Reserve System. This paper was produced under the auspices for the Center for Pacific Basin Studies within the Economic Research Department of the Federal Reserve Bank of San Francisco. 


\title{
MARKET PRICE ACCOUNTING AND DEPOSITOR DISCIPLINE
}

\section{IN JAPANESE REGIONAL BANKS}

\author{
Mark M. Spiegel ${ }^{* \dagger}$ \\ Federal Reserve Bank of San Francisco \\ and \\ Nobuyoshi Yamori \\ Nagoya University
}

May 10, 2004

\begin{abstract}
We examine the determinants of Japanese regional bank decisions concerning pricing unrealized losses or gains to market. We also examine the impact of these decisions on the intensity of depositor discipline, in the form of the sensitivity of deposit growth to bank financial conditions. To obtain consistent estimates of depositor discipline, we first model and estimate the bank pricing-to-market decision and then estimate the intensity of depositor discipline after conditioning for that decision. We find that banks were less likely to price to market the larger were their unrealized securities losses. We also find statistically significant evidence of depositor discipline among banks that elected to price their assets to market. Our results indicate that depositor discipline was more intense for the subset of banks that priced-to-market, suggesting that increased transparency may enhance depositor discipline.
\end{abstract}

Keywords: disclosure, Japanese banking, market discipline JEL Classification nos.: G18, G21

*Corresponding author. Federal Reserve Bank of San Francisco, 101 Market Street, San Francisco, CA, 94105, (415)-974-3241, e-mail: mark.spiegel@sf.frb.org.

$\dagger$ We thank the Postal Life Insurance Foundation of Japan for financial assistance for Yamori. Helpful comments were received from Richard Dennis. Edmund Chiang provided excellent research assistance. Remaining errors are our own. The views expressed in this paper are those of the authors and do not necessarily reflect those of the Board of Governors of the Federal Reserve or the Federal Reserve Bank of San Francisco. 



\section{Introduction}

Private depositors and investors may discipline financial institutions for falling into precarious capital positions, either by requiring higher expected returns for their assets or removing their assets entirely. Such market discipline enhances the financial regulatory environment by increasing bank incentives to maintain adequate capital positions and avoid excessive risk [e.g.Flannery (1998)]. There is ample evidence that market discipline exists among bank bond holders [e.g. Flannery and Sorescu (1996) and Morgan and Stiroh (2001)]. Moreover, a number of studies have documented market discipline among uninsured depositors in the United States. Goldberg and Hudgins (2002) find that the share of uninsured deposits declines among failed institutions in the proximity of their failure date. Park and Peristiani (1998) find that holders of large certificates of deposit by moving their assets to other banks or demanding higher interest rates from their troubled bank.

However, the existence of deposit insurance reduces insured depositor incentives to discipline problem banks. Jordan, Peek, and Rosengren (1999) find that equity holders respond immediately to news concerning enforcement actions, but found only modest declines in deposits. Gilbert and Vaughan (2001) fail to find any evidence of unusual deposit withdrawals or increases in bank interest rate as a result of enforcement announcements. Moreover, Billett, Garfinkel, and O’Neal (1998) and Jordan (2000) find that banks can mitigate the response that does take place by switching from uninsured to insured deposits.

In this paper, we examine the extent of depositor discipline on Japanese banks in 2001. Japanese equity values had fallen dramatically during the 2000 fiscal year. The Nikkei 225 average index fell 36 percent from the end of March 2000 through end-March 2001 (see Figure 1). However, as shown in Figure 2, Japanese banks' security holdings, which consist of both 
stock and bonds, actually increased over this period, both in absolute value and as a share of total assets. By March 2001, Japanese bank securities holdings totaled 175 trillion yen. The increase was primarily due to increased holdings of government bonds, which rose from 46 trillion yen in March 2000 to 73 trillion yen in March 2001. Stock holdings changed little over the period, falling from 46 trillion yen to 44 trillion yen. ${ }^{1}$

Moreover, in 2001 the Japanese government announced a plan to replace its total deposit insurance guarantees by March 2002 with a partial deposit insurance system, where coverage would be limited to 10 million yen per depositor. This reduction in insurance coverage was referred to locally as the "pay-off" policy. The anticipation of the pay-off policy combined with the severe difficulties faced by the Japanese banking system at that time gave Japanese depositors incentives to choose sound banks during fiscal 2001(April 2001-March 2002).

The Japanese experience also sheds light on the implications of bank transparency on the intensity of depositor discipline. In an effort to increase market discipline among Japanese financial firms, the Japanese Business Accounting Council (BAC) released a report in 1999 recommending that Japanese firms, including banks, adopt market price accounting for certain classes of financial products. ${ }^{2}$ While their recommendation was not formally binding, it applied to all certified public accountants (CPAs), and by extension to all listed firms and large unlisted firms $^{3}$ that required the approval of CPAs on their financial statements. The Financial Services Agency adopted the BAC opinion for banks as well.

\footnotetext{
${ }^{1}$ The other security component, foreign securities, increased from 13 trillion yen to 23 trillion yen.

${ }^{2}$ The BAC is an advisory council in the Ministry of Finance. The 1999 report was entitled, "Opinion concerning Accounting Standards for Financial Products."

${ }^{3}$ Large unlisted firms are those having at least 500 million yen in capital or 20 billion yen in debt.
} 
As discussed below, banks had discretion in the timing of compliance with the BAC guidelines in the case of assets listed as "other securities." While market price accounting for trading securities was to be applied for the 2000 fiscal year, which ended March 31, 2001 for most firms, market price accounting for assets in the "other securities" category could be deferred until the 2001 fiscal year, which generally ended March 31, 2002. Nevertheless, most banks voluntarily chose to mark their assets to market early, i.e. to mark them to market for the 2000 fiscal year in March 2001.

Marking assets to market early had both regulatory and informational implications for banks. ${ }^{4}$ The regulatory implications were more direct. Realizing previously-unrealized losses result in a direct hit to a bank's tier-1 capital, after adjustment for taxes. For banks that are already capital-poor, realizing these losses could result in violation of minimum capital requirements, or movement precariously close to those levels. Banks that fell to inadequate capital conditions could be faced with regulatory restrictions, forced to raise capital through costly channels, or in extreme cases could face closure or nationalization.

The informational implications of marking to market in this case were limited by the fact that banks were already required to disclose market values and unrealized profits (or losses) of "other securities" assets as supplementary information in their annual reports. Nevertheless, marking to market may have increased the information sets of some agents, particularly some classes of depositors. Moreover, the regulatory implications of pricing to market raise the possibility that such action also conveys information concerning a bank's true underlying financial condition. Due to their superior information concerning the value of their assets, banks may possess superior information concerning the regulatory consequences of pricing to market.

\footnotetext{
${ }^{4}$ For a review of the literature on firm disclosure, see Healy and Palepu (2001).
} 
Their decision concerning the adoption of market pricing may then signal asset quality to the market.

We examine the impact of bank market pricing decisions on depositor discipline by contrasting the sensitivity of depositors to bank financial conditions among banks that did and did not mark their assets to market early. Of course, the decision concerning whether or not to mark assets to market is likely to be endogenous to bank financial conditions. To deal with the endogeneity of the pricing-to-market decision, we use Lee's (1976) switching regression method. This is a two-step method in which a probit specification is used to estimate the determinants of the bank disclosure decision, and then the residuals from this first stage allow for consistent second-stage estimation of the impact of the bank disclosure decision on depositor discipline.

Our first-stage results are related to the literature on bank disclosure decisions. The literature suggests that voluntary bank disclosure is less than perfect. Gunther and Moore (2000) find that U.S. bank exams affect the accuracy of financial information released to the public. In the absence of regulatory exams, banks underestimate the share of non-performing loans in their balance sheet. Spiegel and Yamori (2004) find that among Japanese credit cooperatives, voluntary disclosure of balance sheet information is less likely among smaller banks and those in weaker financial positions.

Our first-stage results identify two characteristics robustly affecting bank pricing-tomarket decisions: Banks were less likely to price-to-market early the greater were losses on assets designated as "other securities," defined in more detail below. Realizing these losses would adversely affect bank capital positions. Banks were also less likely to price to market the greater were local unemployment levels. 
Our second stage results suggest that pricing-to-market does enhance depositor discipline in terms of growth in deposit levels. We consistently find that deposit growth in the sub-sample of banks that adopted market price accounting is more sensitive to indicators of financial weakness than the other sub-sample. However, the imprecision with which these coefficients are estimated for the sub-sample of banks that failed to price to market precludes formally inferring that these sensitivities are different at statistically significant levels.

The remainder of this paper is divided into six sections. The following section reviews the market-pricing requirements under the BAC standards. Section 3 reviews the data and the accounting methodology used in the study. Section 4 examines our first-stage results concerning the determinants of bank pricing-to-market decisions. Section 5 reviews our second-stage results concerning depositor discipline. Section 6 concludes.

\section{BAC Market-Pricing Requirements}

Under the BAC requirements, which were adopted by the FSA for Japanese banks, accounting requirements differed across asset classes. Japanese firm assets are typically classified into four categories, based on their intended use: The first category is trading securities. These securities are widely traded in financial markets, and have readily available market values. Under market price accounting, trading securities are valued according to their current market prices on firm balance sheets, and price changes in trading securities are incorporated as profits or losses in firm income statements.

The second and third asset categories are "held-to-maturity bonds" and "equities in subsidiaries and related firms," respectively. These assets are not expected to be sold prior to maturity. As such, the BAC values these asset classes on the basis of historical costs, or their 
original purchase price, adjusted for amortization. Market price changes in these assets have no impact on their valuation in firm balance sheets or income statements. The fourth category is labeled "other securities." This category includes any securities that do not neatly fit into the above three categories. For example, cross-share holdings of equities in long-term mutual relationships fall into this category.

The BAC recommended that securities in the "other" category should be marked to market on firm balance sheets based on current market prices, similar to the standards for trading securities. ${ }^{5}$ However, there were several distinctions between the treatment of assets classified as trading securities and those classified as other securities: First, price changes in trading securities were treated as profits and losses in firm income statements in addition to being incorporated in firm capital positions. Price changes in other securities, on the other hand, were only recorded as capital position changes under the "Net Unrealized Losses on Other Securities" category in firm balance sheets. ${ }^{6}$ Second, the BAC recommended that market price accounting for trading securities be applied for the 2000 fiscal year, which ended March 31, 2001 for most firms. However, market price accounting for assets in the "other securities" category could be deferred until the 2001 fiscal year, which generally ended March 31, 2002.

The regulatory impact of marking losses on other securities to market could be quite substantial. For example, consider the impact of the restrictions on a representative bank, Sakura. Table 1 shows the disclosure information released by Sakura concerning its securities holdings at the end of March 2001. It can be seen that a large share of securities held by Sakura, 93 percent,

\footnotetext{
${ }^{5}$ An exception was made for untraded securities, which were to be valued at historical cost adjusted for amortization.

${ }^{6}$ Exceptional losses in other securities, where market prices had declined by more than 50 percent of book values and it was generally agreed that there was little hope for price recovery, were to be treated as income through impairment loss accounting.
} 
were classified into the "other securities" category. Sakura bank did not choose to employ market price accounting for these "other securities" for fiscal year 2000, and therefore was not required to deduct its unrealized losses on these assets, worth 346.6 billion yen, from its capital account. This enhanced Sakura's reported capital position. Given the total level of Sakura's riskadjusted assets of 31.8 trillion yen, the inclusion of the unrealized losses on these assets into Sakura's capital account would have decreased its regulatory capital ratio by 0.56 percent. $^{7}$ This would represent a non-trivial reduction in Sakura's reported 11.91 percent capital ratio.

\section{Data}

\subsection{Sample}

Our sample consists of cross-sectional data for 116 of the 118 Japanese first and second regional banks, with data coming from the period from April 1, 2000 through March 31, 2002, formally the 2000 and 2001 fiscal years. Chubu bank and Kansai Sawayaka bank, which failed during the sample period and whose data is incomplete, are excluded. ${ }^{8}$ Our sample includes 64 first regional banks and 52 second regional banks. We exclude the 18 large Japanese banks, including city banks, long-term credit banks, and trust banks, from our sample for two reasons: First, as this period was a turbulent one for Japanese banking, most of the large Japanese banks experienced mergers over the period, raising troubling accounting issues concerning the assessment of their relative financial conditions. Second, the large banks differ in terms of

\footnotetext{
${ }^{7}$ We deduct only 60 percent of unrealized losses because of the positive tax implications of realizing these losses.

${ }^{8}$ Chubu bank failed in March 2002. Kansai Sawayaka bank started its operation in February 2001 as a successor of failed Koufuku bank. These banks are both second regional banks. Although Ishikawa bank also failed in December 2001, we were able to obtain data for that bank, and it is included.
} 
business lines and operating territories as well as their regulatory exposure [e.g. Spiegel and Yamori, (2004)], from the regional banks, which constitute the bulk of the sample.

Bank financial information was obtained from the Nikkei NEEDS data set. Balance sheet data for the regional banks in our sample are shown in Table 2. The figures demonstrate that as a group regional banks overstated their capital positions by selectively choosing whether or not to mark their other securities to market. The total market value of other securities for the sample fell below their book values by more than 1.3 trillion yen.

Regional data used in the study, such as home prefecture GDP and number of branches, are from Minryoku, which is published by Asahi Shinbun. Prefecture unemployment rates are derived from the Ministry of General Affairs.

95 of the 116 banks in our sample adopted market price accounting (MPA) on their "other securities" assets for the 2000 fiscal year, while 21 banks did not. For simplicity, we designate the banks that chose market price accounting on other securities "MPA banks," and those that did not choose market price accounting on their other securities "non-MPA" banks.

Differences between the banks that did and did not choose to adopt market price accounting are shown in Table 3. The most glaring distinction between MPA and non-MPA banks is the performance of their "other securities" assets. MPA banks earned positive profits on "other securities" assets according to reports in March 2001, while the other securities assets of non-MPA banks suffered losses. This indicates that the performance of the "other securities" assets played a large role in banks' pricing-to-market decision. However, there are notable differences in other dimensions as well. MPA banks tend to be larger than non-MPA banks both in deposits and in asset size. MPA banks also tend to exhibit greater financial strength. The mean capital ratio of MPA banks is 9.26 percent, while that of non-MPA banks is 7.98 percent. 
The data also demonstrates that the ability to avoid marking "other securities" assets to market allowed non-MPA banks to enhance their recorded capital ratios. The mean value of nonMPA banks' risk-adjusted assets was 1,223 billion yen. Marking the 8.258 billion yen in "other securities" losses suffered by these banks to market would lead to a 0.4 percent decrease in nonMPA banks' reported capital ratios at average tax rates of 40 percent. This would leave the recorded capital ratio of non-MPA banks at 7.58 percent. While this figure satisfies domestic capital standards, which require ratios exceeding 4 percent, it falls short of the 8 percent Basel standard for international banks, implying that capital constraints played a role in the decision to mark other securities assets to market.

Differences in the financial conditions of MPA and non-MPA banks are also reflected by differences in their dividend decisions. 91 of the 95 MPA banks, or 96 percent, paid some dividends, while only 17 out of 21 , or 81 percent of the non-MPA banks paid some dividends. It is generally perceived that failure to issue dividends by Japanese banks constitutes a strong signal of financial weakness, as it triggers a regulatory response. Therefore, the discrepancy in the probability of issuing dividends also indicates that non-MPA banks faced inferior financial conditions.

The final columns show movements in deposits by non-MPA and MPA banks over our sample period. It can be seen that non-MPA banks lost deposits over this period, while MPA banks gained deposits. Time deposits in particular dropped sharply in non-MPA banks, by almost 17 percent. However, as depositors had access to information concerning underlying bank fundamentals, and we know that these fundamentals were inferior among non-MPA banks, it is unclear whether the flight of depositors reflected a response to the decision not to disclose, or to the true underlying fundamentals. We therefore investigate this issue further below. 
Lastly, we can see that there was no difference in average interest rate payments between non-MPA and MPA banks during our sample period. This would seem to indicate that depositor discipline manifested itself primarily through the exit of depositors from weak Japanese banks.

\subsection{Measurement of bank capital ratios and other variables}

Because banks differ in their pricing to market decisions, their reported regulatory capital ratios may not truly reflect their relative capital positions. In particular, an MPA bank with a lower reported capital ratio than a non-MPA bank may in fact be in superior financial condition. To calculate comparable capital ratios, we adjust reported capital ratios as follows: For banks subject to international capital standards we first calculate the net value of their unrealized profits or losses. If in net banks hold unrealized profits, 45 percent of the value of these profits are added to their tier-2 capital. If in net banks hold unrealized losses, 60 percent of these unrealized losses are deducted from their tier-1 capital. For banks following domestic capital standards, unrealized profits are not counted. However, the treatment of their unrealized losses depends on their pricing-to-market decision. For MPA banks, unrealized losses are counted at 60 percent of their value against tier-1 capital. For non-MPA banks, unrealized losses are not counted against regulatory capital (see Table 4).

To comparably reflect differences in relative capital positions between MPA and nonMPA banks, we adjust the tier-1 capital positions of the MPA banks. In particular, for MPA banks that had losses on "other securities," we add the value of their reported "net unrealized losses/risk assets," which is included in the capital sections of their balance sheets, to their 
reported tier-1 regulatory capital. ${ }^{9}$ To obtain a comparable measure of tier- 2 capital, we subtract 45 percent of the unrealized profits on "other securities" of the MPA banks subject to BIS accounting standards. Finally, for MPA banks subject to domestic regulatory standards that had profits on "other securities" and non-MPA banks, their reported regulatory capital is unaffected by their profits or losses on "other securities," so we simply use these reported figures. We term this comparable modified capital ratio CAPRAT, which is defined as the sum of adjusted tier-1 and tier-2 capital divided by total risk-adjusted assets.

We define the ratio of unrealized losses or profits on other securities over risk assets as OTHER. A negative value of OTHER implies that the use of market-price accounting on other securities would have a negative impact on bank regulatory capital ratios.

The impact of these unrealized profits or losses on other securities can be substantial. For example, Chiba bank had unrealized profits on other securities equal to 16.60 billion yen. Chiba followed BIS capital standards and employed market price accounting, which resulted in reported "net unrealized profits on other securities" equal to 9.74 billion yen in the capital account section of their balance sheet. The difference stems from tax adjustments, which reduced these gains by 42 percent. Chiba's reported capital ratio was 10.45 percent, including 340 billion yen in Tier 1 capital, 168.47 billion yen in Tier 2 capital, and 4.86 trillion yen in risk assets. ${ }^{10}$ However, Chiba's Tier 2 capital also includes 7.47 billion yen in unrealized profits on other securities, leaving Chiba's true capital ratio at 10.31 percent and Chiba's value of OTHER equal to 0.34 percent.

\footnotetext{
${ }^{9}$ We use unconsolidated figures regarding profits or losses on holdings of "other securities" when available, but some banks only release consolidated figures. In these cases, the consolidated figures were used. Since the number of regional bank subsidiaries is strictly limited, disparities between the unconsolidated and consolidated figures are likely to be minor.

${ }^{10}$ Final capital ratios include a small adjustment to account for minority shareholders and other residual claimants.
} 
Alternatively, consider the example of Towa bank, which also employed market price accounting but fell under the domestic capital standard. Towa reported "net unrealized losses on other securities" in its balance sheet capital account equal to 8.14 billion yen. Its gross unrealized losses on other securities were equal to 13.91 billion yen. After tax adjustments reduced Towa's balance sheet value of gross unrealized losses 42 percent, Towa's reported capital ratio was 6.39 percent, including 55.94 billion yen in tier-1 capital, 6.97 billion yen in tier-2 capital, and 982.42 billion yen in risk assets. Consequently, if Towa had not priced to market it would have reported a capital ratio of 7.23 percent. Towa's OTHER value is then equal to -1.42 percent.

The remaining independent variables include DIVIDEND, a dummy variable which takes unit value if a bank paid dividends and zero otherwise. Failure to issue dividends is generally considered an indicator of financial weakness [Spiegel and Yamori (2004)]. We define ASSET, the log of total assets, as a proxy for bank size. We define $C O M P$, measured as the ratio of deposits in the home prefecture over the number of bank branches in the prefecture, as an indicator of the intensity of domestic competition. Because we are interested in all relevant competitors, we include the number of local credit cooperatives in the denominator of COMP. ${ }^{11}$ As an indicator of local economic conditions we include the home prefecture average unemployment rate for the 2000 calendar year, $U 2000$.

\section{First-Stage Results: Determinants of Pricing-to-market Decisions}

In this section, we report the results of the first stage of the estimation process, estimated as a probit specification of the determinants of the banks' pricing-to-market decision. Our dependent variable is therefore a qualitative variable, taking unit value when a bank chose

\footnotetext{
${ }^{11}$ Deposit data are measured as of March 31, 2001, while branch figures are measured on November 1, 2000 due to data availability.
} 
market price accounting for their "other securities" for the 2000 fiscal year, and zero value otherwise.

Our primary variable of interest is $O T H E R$, the ratio of unrealized profits on other securities over assets. We would expect a positive sign on the OTHER variable, as that variable is directly negatively correlated with a reduction in a bank's regulatory capital that would result from pricing other securities to market.

We also include CAPRAT, a measure of adjusted bank capital ratios, to examine whether the decision concerning the use of market-price accounting was influenced by bank financial strength. Banks with lower capital ratios would be more likely to suffer adverse regulatory implications of marking their losing other securities assets to market. In particular, if the capital ratio of a bank subject to international capital standards fell below 8 percent, or below 4 percent for banks with only domestic operations, then that bank would be subject to regulatory intervention by the Financial Services Agency. ${ }^{12}$ As such, we would expect that if bank financial conditions affected their pricing-to-market decision, the effect would be positive. We would similarly expect a positive coefficient on our alternative indicator of financial strength,

\section{DIVIDEND.}

For the other variables, Spiegel and Yamori (2004) found that bank size was positively correlated with the willingness of Japanese credit cooperatives to voluntarily release balance sheet information, and we would similarly expect a positive coefficient on ASSET, as larger banks should be more willing to mark their other securities losses to market. The expected sign on $C O M P$ is unclear. The greater the intensity of local competition, the more bank managers may want to maintain independence, suggesting a reluctance to adopt market price accounting.

\footnotetext{
${ }^{12}$ An additional distinction between the international and domestic capital standards is that the international standard allows banks to add 45 percent of unrealized profits on securities to Tier 2 capital, while the domestic standard does not.
} 
However, competitive pressure may force banks to adopt market price accounting at higher rates to distinguish themselves from their competitors. Finally, we would expect that willingness to price to market would be greater the healthier were local economic conditions, and therefore expect a negative coefficient on $U 2000$.

To account for the different critical capital standards faced by domestic and international banks, we also report results with the banks that follow the $B I S$ international capital standards excluded. 14 of the 116 banks in our sample were subject to the BIS standards. All of these banks chose to price their returns on other securities to market.

Our results are shown in Table 5. The first two columns represent the results using normal standard errors, while the final four columns represent the results using White's heteroscedasticity-corrected standard errors with and without the addition of the DIVIDEND indicator of bank financial strength.

Two variables robustly enter significantly as determinants of bank willingness to price their other securities to market, OTHER and $U 2000$. The OTHER variable is particularly robust. It enters significantly positive with relatively similar coefficient estimates, both with and without the inclusion of the BIS banks. The large point estimates on these variables also suggest that it is economically powerful.

The other variable that robustly enters with at least 10 percent statistical significance is U2000, our proxy for local economic conditions. This variable enters with its expected negative sign, indicating that banks from prefectures experiencing economic difficulties are less likely to choose to price-to-market. The coefficient point estimate also indicates that the variable is economically significant. 
Somewhat surprisingly, both of the measures of bank financial conditions, CAPRAT and DIVIDEND are quite insignificant. This result may indicate that while financial conditions are related to the regulatory costs of pricing to market for banks close to their regulatory thresholds, they are irrelevant for the many banks that are not in the neighborhoods of these thresholds.

As a robustness check, we decompose the CAPRAT measure into two ratios representing the tier-one and tier-two capital ratios. We designate these variables TICAPRAT and T2CAPRAT. The results for these alternative measures are shown in Table 6 . It can be seen that the decomposition of the capital ratio has little impact on our results. The same variables enter significantly, with similar coefficient estimates. We therefore conclude that there is little difference in this decomposition, and do not pursue it below in our second stage.

In summary, our first-stage results suggest that the primary determinant of a bank pricing-to-market decision is that bank's unrealized profits or losses on other securities. Qualitatively, this result makes sense. Since banks are required to post these figures elsewhere, the informational content of pricing-to-market appears to have a limited impact on bank decisions. The primary impact of pricing-to-market is the regulatory impact, which is a function of these unrealized profits and losses.

\section{Second-Stage Results: Depositor Discipline}

\subsection{Methodology}

In this section, we examine the relative intensity of depositor discipline faced by banks that did and did not choose to price their assets to market. Of course, we must adjust for the fact that the pricing-to-market decision is itself a function of bank characteristics. We therefore estimate the depositor responses in a specification that accounts for the bank pricing-to-market 
decision, as in Lee's (1976) switching regression method. The details of our estimation method are included in the Appendix. Essentially, the methodology is analogous to a Heckman procedure with the distinction that there is no data censoring. Using our base probit specification above, we estimate a weighting variable according to the method described in the appendix. The inclusion of this weighting variable allows us to obtain consistent estimates for the depositor responses to bank conditions in our second stage estimation under ordinary least squares. We then report the results of these second-stage regressions in this section.

Our explanatory variables are similar to those included in the first stage of estimation, with the exception that we now include unemployment rates in 2001 (U2001), rather than 2000, to reflect the fact that depositor responses were made over the entire year, while pricing-tomarket decisions were made early in the year (March 2000). Our primary focus is on the measures of bank financial strength, CAPRAT and DIVIDEND. Evidence of depositor discipline would entail these variables having a significant impact on our indicators of depositor responses, including a positive impact on deposit growth measures and a negative impact on bank interest rates.

We also include ASSET as a proxy for bank size. We would expect the rate of deposit growth to be increasing and the average interest rate paid on deposits to be decreasing in bank size, as larger banks appeared to enjoy diminished, but perhaps still positive protection under "too-big-to-fail" considerations. ${ }^{13}$

We include the $O T H E R$ variable to examine whether profits on other securities played a role in affecting depositor behavior independent of its impact through the bank pricing-to-market decision. However, we would not expect the magnitude of OTHER to impact depositors, because we have already adjusted for bank financial strength and have conditioned for the banks' pricing-

\footnotetext{
${ }^{13}$ See Spiegel and Yamori (2004) for a discussion of the evolution of too-big-to-fail policy in Japan.
} 
to-market decision. In addition, depositors may consider the banks' OTHER variable a noisy indicator of bank financial strength.

We introduce $C O M P$ as a measure of local competitive conditions. We would expect a higher level of COMP to correspond to greater intensity of depositor discipline, as local depositors would have greater capacity to switch out of an underperforming bank to one in a more sound financial position.

Finally, we include $U 2001$ as a measure of local economic conditions. We would expect deposit growth to be decreasing in local unemployment.

\subsection{Results}

Our second-stage results are shown in Table 7. We estimate the two step process for the two sub-samples with both CAPRAT and DIVIDEND included together, and then each included separately.

Our results show that both estimates of bank financial strength, CAPRAT and DIVIDEND, have a statistically significant impact on growth in total deposits for the sub-sample of banks that adopted market pricing. The point estimates of the variables indicate that they have an economically significant impact on deposit growth as well. For example, the point estimates from the specification including both variables suggests that a one-percent increase in a bank's capital ratio would result in a 2.1 percent increase in total deposits. The same specification suggests that issuing dividends increases expected growth rates by 14.3 percent, and 19.7 percent when the CAPRAT variable is excluded.

The evidence for depositor discipline among the sub-sample of banks that did not pursue market pricing is more mixed. The CAPRAT variable is statistically insignificant when the 
DIVIDEND variable is included, although it does enter significantly with its expected positive sign when this variable is excluded. Even for this specification, however, the point estimate for the sub-sample of banks that failed to pursue market pricing is 24 percent lower than that for the market-pricing sub-sample. This suggests that depositors in the non-MPA sample are less sensitive to bank financial strength than those in the MPA sample. However, the imprecision of this estimate precludes any formal inference that the coefficient for the market-pricing subsample is larger than that for the non-MPA sub-sample at standard significance levels.

The results for the DIVIDEND variable are similar. The DIVIDEND variable enters significantly positive for the non-MPA sub-sample, but with a coefficient estimate that is substantially smaller than that obtained for the market-pricing sub-sample (about one-half the size). Indeed, for the final specification in which CAPRAT is excluded, the difference in coefficient estimates between the MPA and non-MPA sub-samples is statistically significant at a five-percent confidence level.

For the remaining variables, the only one that enters robustly is the COMP variable, which is robustly positive for the MPA sub-sample. The most surprising result is that for the U2001 variable under market pricing, which suggests that increased unemployment is significantly positively related to total deposit growth. One possible explanation for this surprising result is that depositors in areas with higher unemployment rates switched into safer assets, such as bank deposits, in response to the more precarious local economic conditions.

The results for the determinants of growth rates in time deposits are reported in Table 8 . As deposit insurance protection for time deposits was scheduled to be reduced after April 2002, we would expect that depositors holding time deposits would be more sensitive to bank financial conditions than depositors holding demand deposits. Indeed, this seems to be the case. We find 
that CAPRAT has a positive impact on time deposit growth with slightly higher point estimate values for the MPA sub-sample. The coefficient values on DIVIDEND also enter significantly with the correct sign and almost identical point estimates to those found for overall deposit growth. Nevertheless, our qualitative results are quite similar to those for total deposit growth.

In contrast, we obtain markedly lower point estimates for the non-MPA sub-sample, and these are highly insignificant. However, as these coefficients are very imprecisely measured, one cannot formally conclude that growth rates in time deposits for the MPA sample are more sensitive than those for the non-MPA sample at standard significance levels.

The remaining variables are all insignificant, with the exception of the ASSET variable, which enters negatively and significantly for the MPA sub-sample. This result is somewhat surprising, although it may reflect shrinkage in some larger regional banks in response to the realization that they no longer enjoyed too-big-to-fail regulatory protection. The lack of significance of any of the variables for our non-MPA sample is likely to be attributable to our small sample as well as the fact that many depositors at non-MPA banks had already exercised their discipline by March 2001 by previously removing their deposits. Many of these non-MPA banks had already been known to be suffering financial difficulties for some time. ${ }^{14}$

Overall, however, the data strongly suggest that there was evidence of depositor discipline in deposit levels for the MPA sub-sample, as both bank capital ratios and dividend issuances were positively related to both growth rates in total and time deposits. There was also mixed evidence concerning depositor discipline for the non-MPA sample, particularly in the case of total deposit growth rates. Nevertheless, the non-MPA sample coefficient estimates were consistently lower than those for the MPA sample. This suggested that the intensity of market

\footnotetext{
${ }^{14}$ Recall that while we have a small number of observations of non-MPA regional banks, our sample does come close to the universe of Japanese regional banks, with 114 of the total 116 banks.
} 
discipline was greater for the MPA sample. However, the large standard errors for the non-MPA sample implied that we were only able to formally identify a difference at standard confidence levels in the case of the sensitivity of total deposit growth to bank dividend decisions. In that case, we do find that depositors at MPA banks were more sensitive to whether or not banks issued dividends at a five-percent confidence level.

\section{Conclusion}

This paper examines the determinants and consequences of Japanese regional bank decisions concerning pricing their unrealized losses on other securities to market. Our results concerning the determinants of bank pricing-to-market decisions suggested that the primary consideration was the impact that pricing-to-market would have on a bank's regulatory status. Bank decisions were quite sensitive to the magnitude of the unrealized securities losses they were holding, which was directly proportional to the regulatory hit that pricing-to-market would entail. This result was unsurprising, as Japanese banks revealed their asset positions elsewhere in their public statements.

We also found two primary results concerning depositor discipline. First, for the sample of banks that chose to price their securities to market, we found significant evidence of depositor discipline, in the form of sensitivity of both deposit growth rates to bank financial conditions. Second, comparing the two sub-samples, we found that the point estimates for the pricing-tomarket sub-sample indicated greater sensitivity to bank financial conditions than the non-pricingto-market sub-sample. However, the large estimated standard errors for the non-pricing-tomarket sub-sample largely precluded formal inferences of a coefficient difference. One notable exception was the impact of a bank's dividend issue decision on total deposit growth. In this 
case, we found growth in total deposits among the sub-sample of MPA depositors to be more sensitive to dividend issues than the non-MPA sub-sample at a five percent confidence level.

Our results also shed light on the credibility of government announcements concerning banking policies. The bulk of the literature finds that to the extent that depositor discipline takes place, it does so when deposits are either explicitly uninsured or when the credibility of the insurance regime is in question. During our sample period, depositors were told that a regime change to partial depositor insurance was imminent. The fact that we do find evidence that depositors were concerned about bank financial conditions suggests that the Japanese government's announcement that deposit insurance would soon be only partial had some credibility with the public. 


\section{APPENDIX}

\section{Estimation methodology}

As discussed above, we account for the endogeneity of the pricing-to-market decision by using Lee's (1976) two-stage method. ${ }^{15}$ Our first stage regression consists of the PROBIT estimation for the full sample in Table $5 .{ }^{16}$ We define the PROBIT specification as

$$
I_{i}^{*}=\gamma_{0}+\gamma_{1} Z_{i}-\varepsilon_{i}^{*}
$$

where $I_{i}^{*}$ represents the qualitative bank decision concerning pricing to market, $Z_{i}$ is our vector of explanatory variables, $\gamma_{0}$ and $\gamma_{1}$ are our parameters to be estimated, and $\varepsilon_{i}^{*}$ is and i.i.d. disturbance term.

Let $\hat{\gamma}_{0}$ and $\hat{\gamma}_{1}$ represent our first-stage estimates. We then construct an estimate of $\psi_{i}$ which is defined as

$$
\widehat{\psi}_{i}=\hat{\gamma}_{0}+\hat{\gamma}_{1} Z_{i}
$$

We then calculate the density and distribution functions of the standard normal distribution of $\widehat{\psi}_{i}$, which we define as $\phi\left(\widehat{\psi}_{i}\right)$ and $\Phi\left(\widehat{\psi}_{i}\right)$ respectively. Define $\widehat{W}_{i}^{m p a}$ and $\widehat{W}_{i}^{\text {nmpa }}$ as the weighting functions for the sub-samples conditional on pricing-to-market and not pricingto-market. Define $\widehat{W}_{i}^{\text {mpa }}$ and $\widehat{W}_{i}^{\text {nmpa }}$ are calculated as

$$
\widehat{W}_{i}^{m p a} \equiv \frac{\phi\left(\hat{\psi}_{i}\right)}{\Phi\left(\hat{\psi}_{i}\right)}
$$

and

$$
\widehat{W}_{i}^{n m p a} \equiv \frac{\phi\left(\hat{\psi}_{i}\right)}{1-\Phi\left(\hat{\psi}_{i}\right)}
$$

We then can estimate the second stage consistently by running the two sub-samples separately under ordinary least squares with the weighting functions included. In the case of deposit growth (Table 7) the specifications can be written: ${ }^{17}$

$$
\Delta D_{i}^{m p a}=\beta_{0}^{m p a}+X_{i}^{m p a} \beta^{m p a}-\widehat{W}_{i}^{m p a} \sigma^{m p a}+e_{i}^{m p a}
$$

\footnotetext{
${ }^{15}$ For a simple summary, see Maddala (1983), chapters 8 and 11.

${ }^{16}$ For the purposes of calculating the weighting variable, only the coefficient estimates matter, so it does not matter whether the first stage is estimated with or without correcting standard errors for heteroscedasticity.

${ }^{17}$ The methodology used when the determinants of time deposit growth or average interest rates on time deposits are estimated is identical.
} 
and

$$
\Delta D_{i}^{n m p a}=\beta_{0}^{n m p a}+X_{i}^{n m p a} \beta^{n m p a}-\widehat{W}_{i}^{n m p a} \sigma^{n m p a}+e_{i}^{n m p a}
$$

where $\Delta D_{i}^{j}$ represents the growth in total deposits, $X_{i}^{j}$ is a vector of explanatory variables, $\beta_{0}^{j}$ and $\beta_{i}^{j}$ are the parameters to be estimated, $\sigma_{i}^{j}$ is the coefficient estimates on $\widehat{W}_{i}^{j}$, and $\varepsilon_{i}^{j}$ is and i.i.d. disturbance term $\left.(j=m p a, n m p a)\right)$.

Define the residuals of these two regressions as $\varepsilon_{i}^{m p a}$ and $\varepsilon_{i}^{n m p a}$ respectively. We then use these residual estimates to obtain our estimates of the covariance matrix

$$
\hat{\boldsymbol{\sigma}}_{m p a}^{2}=\frac{1}{N_{m p a}} \sum_{i=1}^{N_{m p a}}\left[\left(\hat{\boldsymbol{\varepsilon}}_{i}^{m p a}\right)^{2}+\left(\hat{\boldsymbol{\sigma}}_{i}^{m p a}\right)^{2}\left(\hat{\psi}_{i}\right) \widehat{W}_{i}^{m p a}\right]
$$

and

$$
\hat{\boldsymbol{\sigma}}_{\text {nmpa }}^{2}=\frac{1}{N_{\text {nmpa }}} \sum_{i=1}^{N_{\text {nmpa }}}\left[\left(\hat{\boldsymbol{\varepsilon}}_{i}^{n m p a}\right)^{2}+\left(\hat{\boldsymbol{\sigma}}_{i}^{\text {nmpa }}\right)^{2}\left(\widehat{\psi}_{i}\right) \widehat{W}_{i}^{\text {nmpa }}\right]
$$

where $N_{\text {mpa }}$ and $N_{\text {nmpa }}$ represent the number of banks choosing disclosure and non-disclosure respectively. Our estimated standard errors are then adjusted for heteroscedasticity by weighting by using our estimated parameters to compute error variances and then running weighted least squares. 
Figure 1: Nikkei 225 Average, End of Fiscal Year values.

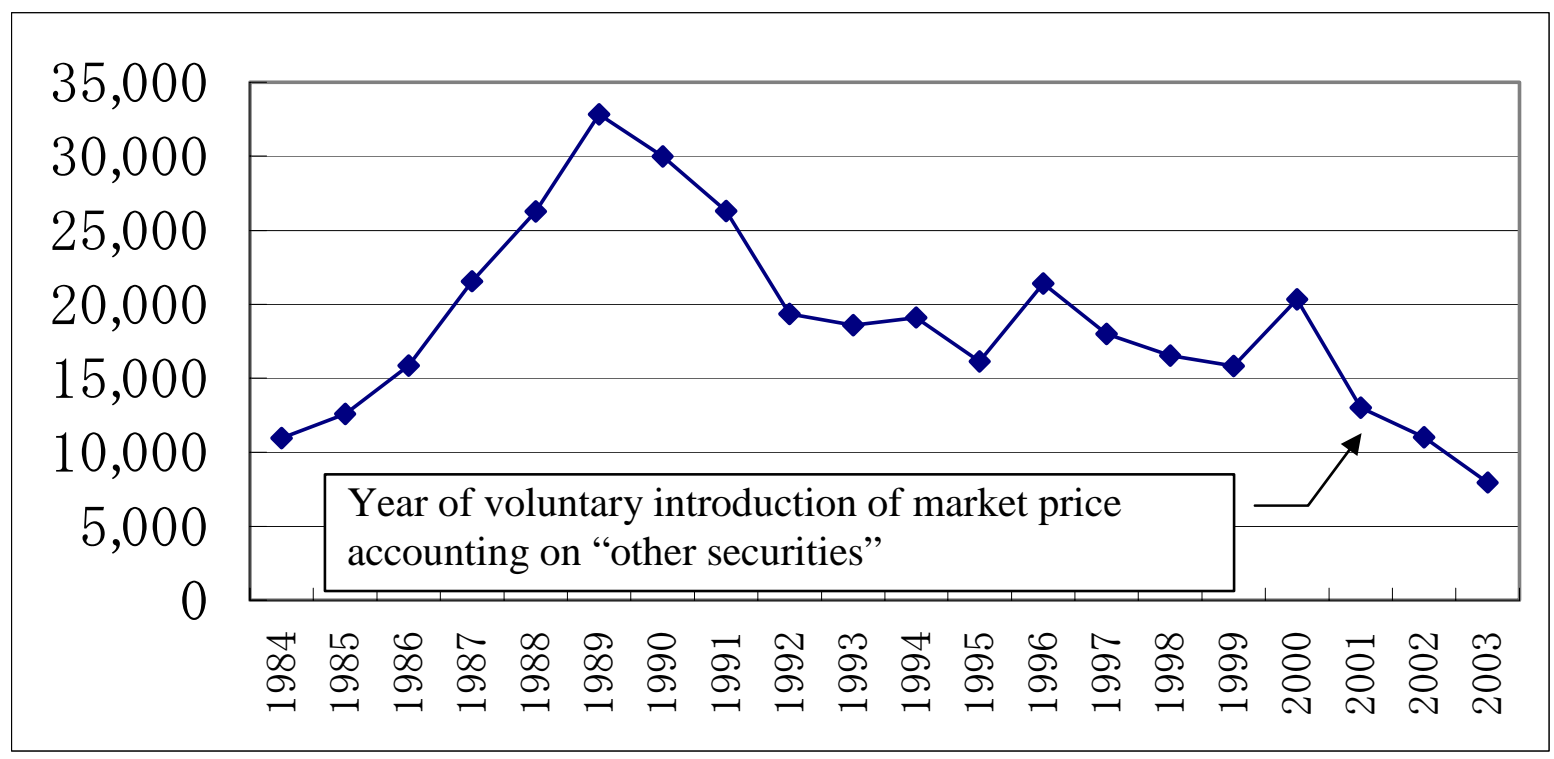

Notes: Plot of Nikkei 225 average, from 1984 through 2003. Values are taken at end of March for stated year. Arrow indicates year when voluntary introduction of market pricing on "other securities" was introduced. 
Figure 2: Securities Holdings by Japanese banks.

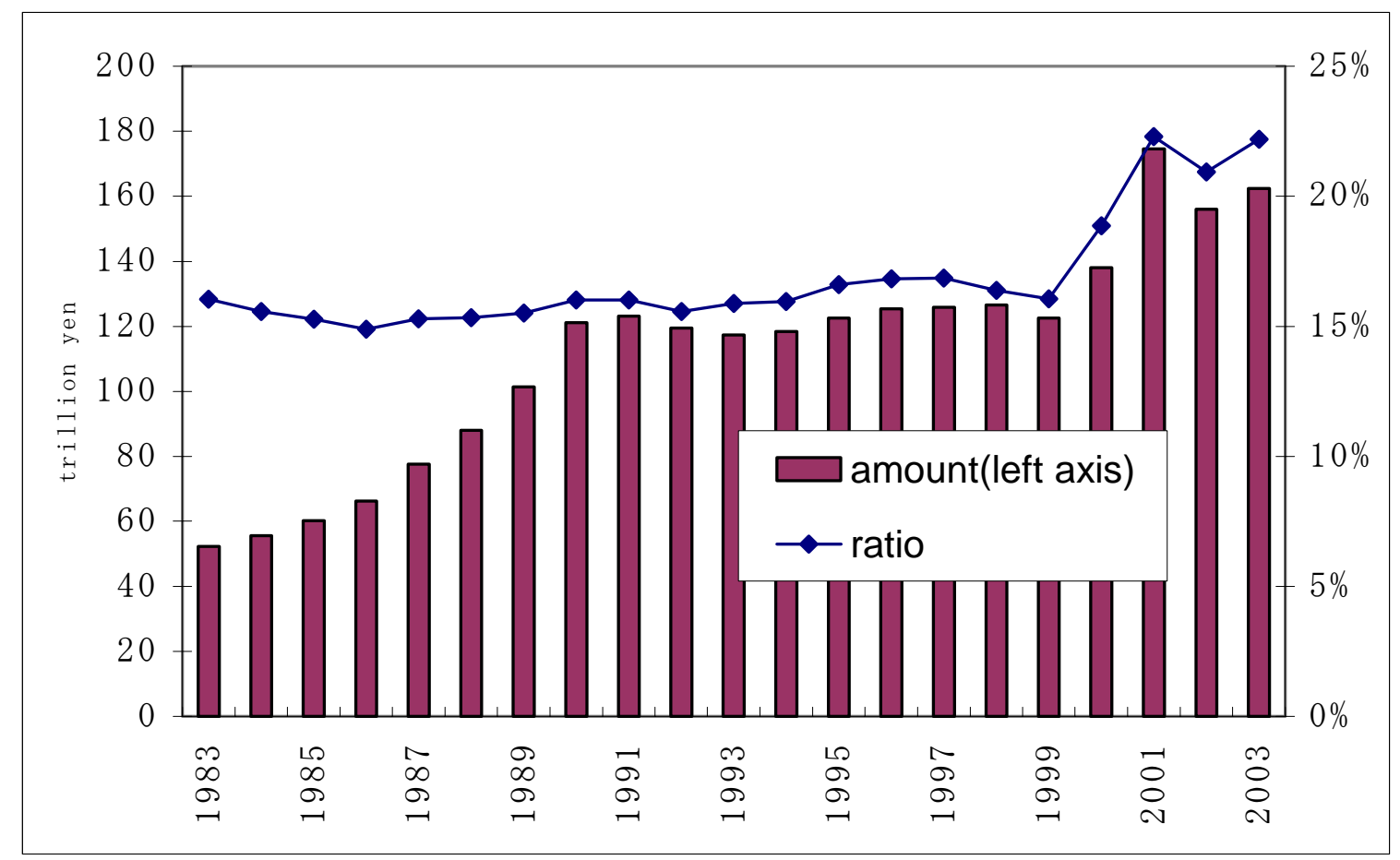

Notes: Figures are end of March. Securities include national government bonds, corporate bonds, and equities. Ratio is defined as Securities divided by total assets. Sample includes all domestically-licensed banks since 1994. Before 1994, trust banks that are subsidiaries of security companies and foreign banks are excluded. Source: Bank of Japan. 
Table 1. Securities holdings of Sakura Bank, March 2001.

\begin{tabular}{|c|c|c|c|c|}
\hline \multirow{2}{*}{\multicolumn{2}{|c|}{ Asset Class }} & \multicolumn{3}{|r|}{ billion yen } \\
\hline & & \multirow{2}{*}{$\begin{array}{l}\text { Balance Sheet } \\
\text { Value } \\
422.4\end{array}$} & \multirow{2}{*}{$\begin{array}{l}\text { Market Value } \\
422.6\end{array}$} & \multirow{2}{*}{$\begin{array}{l}\text { Difference } \\
0.2 \\
\end{array}$} \\
\hline $\begin{array}{l}\text { Trading } \\
\text { Securities }\end{array}$ & & & & \\
\hline \multirow{2}{*}{$\begin{array}{l}\text { held-to- } \\
\text { maturity } \\
\text { securities }\end{array}$} & Marketable & 0.0 & 0.0 & 0.0 \\
\hline & $\begin{array}{l}\text { non- } \\
\text { marketable }\end{array}$ & 7.1 & - & - \\
\hline \multirow{2}{*}{$\begin{array}{l}\text { Stocks of } \\
\text { subsidiaries and } \\
\text { affiliates }\end{array}$} & Marketable & 64.3 & 68.6 & 4.2 \\
\hline & $\begin{array}{l}\text { non- } \\
\text { marketable }\end{array}$ & 266.5 & - & - \\
\hline \multirow{2}{*}{$\begin{array}{l}\text { Other } \\
\text { Securities }\end{array}$} & Marketable & 9316.5 & 8969.9 & -346.6 \\
\hline & $\begin{array}{l}\text { non- } \\
\text { marketable }\end{array}$ & 459.9 & - & - \\
\hline
\end{tabular}

Note: Table describes securities holdings of Sakura bank in various asset classes in March 2001. Marketable portion of "other securities" assets are those over which the bank had discretion in pricing to market. Value of marketable other securities on Sakura Bank balance sheet exceeded true market value by 346.6 billion yen. Source: Nikkei NEEDS data set. 
Table 2. Summary Statistics of Securities Holdings of 116 Regional Banks.

\begin{tabular}{|l|l|r|r|r|}
\cline { 3 - 5 } \multicolumn{2}{c|}{} & $\begin{array}{l}\text { Value } \\
\text { on B/S }\end{array}$ & $\begin{array}{l}\text { Market } \\
\text { values }\end{array}$ & Differences \\
\hline \multirow{2}{*}{ Trading Securities } & & 2,203 & - & - \\
\hline $\begin{array}{l}\text { held-to-maturity } \\
\text { securities }\end{array}$ & Marketable & 990 & 1,019 & 29 \\
\cline { 2 - 5 } & Non-marketable & 429 & - & - \\
\hline $\begin{array}{l}\text { Stocks of } \\
\text { subsidiaries and } \\
\text { affiliates }\end{array}$ & Marketable & 69 & 66 & -2 \\
\cline { 2 - 5 } & Non-marketable & 449 & - & - \\
\hline \multirow{2}{*}{ Other Securities } & Marketable & 36,687 & 38,021 & 1,333 \\
\cline { 2 - 5 } & Non-marketable & 1,205 & - & - \\
\hline
\end{tabular}

Notes: Table describes securities holdings of 116 of Japan's 118 regional banks. Chubu bank, which failed in March 2002, and Kansai Sawayaka bank, which started its operations in February 2001 as a successor of failed Koufuku bank, are excluded. Source: Nikkei NEEDS data set. 
Table 3. Differences between Non-MPA and MPA banks.

$\underline{\text { Non-MPA }} \underline{\text { MPA }}$

Number of Banks

21

95

Number of Banks Paying Some Dividends

17

91

Bank Capital Ratios (percent)

7.98

9.26

Average Deposit Interest (2001 fiscal yr)

0.002

0.002

\section{Balance sheet levels (million yen)}

Deposits

Assets

Unrealized profits on "other securities"
$1,777,558$

$1,985,229$

$-8257.67$
$2,062,471$

$2,354,047$

26248.4

Changes from March 2001 to March 2002

Deposits (3-02/3-01)

Time Deposits (3-02/3-01)

Demand Deposits (3-02/3-01)
0.97

0.832

1.277
1.006

0.892

1.227

Notes: Balance sheet values are recorded as of March 31, 2001. "Non-MPA" refers to banks that did not price "other securities" assets to market, while "MPA" refers to banks that did price their "other securities" assets to market in March 2001. Source: Nikkei NEEDS data set. 
Table 4. Treatment of Unrealized Profits or Losses on Other Securities

\begin{tabular}{|c|c|c|}
\hline Capital Std. & $\begin{array}{c}\text { Treatment of Unrealized } \\
\text { Profits }\end{array}$ & $\begin{array}{c}\text { Treatment of Unrealized } \\
\text { Losses }\end{array}$ \\
\hline BIS Std. & $45 \%$ into Tier 2 & $60 \%$ into Tier 1 \\
\hline Domestic Std. MPA & Not considered & $60 \%$ into Tier 1 \\
\hline Domestic Std. Non-MPA & Not considered & Not considered \\
\hline
\end{tabular}

Notes: Table summarizes regulatory treatment of unrealized profits for Japanese banks. Banks subject to BIS standards were required to count 45 percent of unrealized losses on other securities into tier 2 capital and 60 percent of unrealized losses on other securities into tier-1 capital. For domestic standard banks, those choosing to price their assets to market were required to count 60 percent of unrealized losses on other securities into tier-1 capital. 
Table 5. Probit Estimation Results for Pricing to Market Decision

\begin{tabular}{|c|c|c|c|c|c|c|}
\hline Variable & $\begin{array}{c}\text { Full } \\
\text { Sample }\end{array}$ & $\begin{array}{c}\text { BIS } \\
\text { Banks } \\
\text { omitted }\end{array}$ & $\begin{array}{c}\text { Full } \\
\text { Sample } \\
\text { Robust } \\
\text { Std. } \\
\text { Errors }\end{array}$ & $\begin{array}{c}\text { BIS } \\
\text { Banks } \\
\text { omitted } \\
\text { Robust } \\
\text { Std. } \\
\text { Errors }\end{array}$ & $\begin{array}{c}\text { Full } \\
\text { Sample } \\
\text { Robust } \\
\text { Std. } \\
\text { Errors }\end{array}$ & $\begin{array}{c}\text { BIS } \\
\text { Banks } \\
\text { omitted } \\
\text { Robust } \\
\text { Std. } \\
\text { Errors }\end{array}$ \\
\hline CONSTANT & $\begin{array}{c}3.763 \\
(4.014)\end{array}$ & $\begin{array}{c}4.167 \\
(4.054)\end{array}$ & $\begin{array}{c}3.763 \\
(4.001)\end{array}$ & $\begin{array}{c}4.167 \\
(4.064)\end{array}$ & $\begin{array}{c}2.952 \\
(4.137)\end{array}$ & $\begin{array}{c}3.361 \\
(4.208)\end{array}$ \\
\hline ASSET & $\begin{array}{c}0.110 \\
(0.213)\end{array}$ & $\begin{array}{c}0.075 \\
(0.217)\end{array}$ & $\begin{array}{c}0.109 \\
(0.218)\end{array}$ & $\begin{array}{c}0.075 \\
(0.225)\end{array}$ & $\begin{array}{c}0.163 \\
(0.226)\end{array}$ & $\begin{array}{c}0.129 \\
(0.233)\end{array}$ \\
\hline CAPRAT & $\begin{array}{c}0.107 \\
(0.129)\end{array}$ & $\begin{array}{c}0.098 \\
(0.130)\end{array}$ & $\begin{array}{c}0.107 \\
(0.112)\end{array}$ & $\begin{array}{c}0.098 \\
(0.114)\end{array}$ & $\begin{array}{c}0.018 \\
(0.155)\end{array}$ & $\begin{array}{c}0.010 \\
(0.160)\end{array}$ \\
\hline OTHER & $\begin{array}{c}0.937 * * \\
(0.266)\end{array}$ & $\begin{array}{c}0.918 * * \\
(0.267)\end{array}$ & $\begin{array}{c}0.937 * * \\
(0.238)\end{array}$ & $\begin{array}{c}0.918 * * \\
(4.260)\end{array}$ & $\begin{array}{c}0.973 * * \\
(0.227)\end{array}$ & $\begin{array}{c}0.952 * * \\
(0.225)\end{array}$ \\
\hline COMP & $\begin{array}{l}-0.736 \\
(0.625)\end{array}$ & $\begin{array}{c}-0.711 \\
(0.627)\end{array}$ & $\begin{array}{c}-0.736 \\
(0.625)\end{array}$ & $\begin{array}{l}-0.711 \\
(0.627)\end{array}$ & $\begin{array}{l}-0.696 \\
(0.630)\end{array}$ & $\begin{array}{c}-0.669 \\
(0.634)\end{array}$ \\
\hline$U 2000$ & $\begin{array}{c}-0.259 * \\
(0.154)\end{array}$ & $\begin{array}{c}-0.264 * \\
(0.155)\end{array}$ & $\begin{array}{c}-0.259 * * \\
(0.127)\end{array}$ & $\begin{array}{c}-0.264 * * \\
(0.129)\end{array}$ & $\begin{array}{c}-0.240 * \\
(0.129)\end{array}$ & $\begin{array}{c}-0.245^{*} \\
(0.131)\end{array}$ \\
\hline DIVIDEND & - & - & - & - & $\begin{array}{c}0.518 \\
(0.645)\end{array}$ & $\begin{array}{c}0.510 \\
(0.653)\end{array}$ \\
\hline $\begin{array}{l}\text { \# of } \\
\text { observations }\end{array}$ & 116 & 102 & 116 & 102 & 116 & 102 \\
\hline $\begin{array}{l}\text { Pseudo } \\
\text { R-squared }\end{array}$ & 0.342 & 0.311 & 0.342 & 0.311 & 0.347 & 0.316 \\
\hline $\begin{array}{l}\text { Log } \\
\text { likelihood }\end{array}$ & -36.101 & -35.754 & -36.101 & -35.754 & -35.838 & -35.499 \\
\hline
\end{tabular}

Note: Results of first stage PROBIT estimation. Figures in parentheses are standard errors. ** indicates statistical significance at $5 \%$ confidence level. * indicates statistical significance at $10 \%$ confidence level. 
Table 6. Probit Estimation Results for Pricing to Market Decision

\begin{tabular}{|c|c|c|c|c|c|c|}
\hline Variable & $\begin{array}{c}\text { Full } \\
\text { Sample }\end{array}$ & $\begin{array}{c}\text { BIS } \\
\text { Banks } \\
\text { omitted }\end{array}$ & $\begin{array}{c}\text { Full } \\
\text { Sample } \\
\text { Robust } \\
\text { Std. } \\
\text { Errors }\end{array}$ & $\begin{array}{c}\text { BIS } \\
\text { Banks } \\
\text { omitted } \\
\text { Robust } \\
\text { Std. } \\
\text { Errors }\end{array}$ & $\begin{array}{c}\text { Full } \\
\text { Sample } \\
\text { Robust } \\
\text { Std. } \\
\text { Errors }\end{array}$ & $\begin{array}{c}\text { BIS } \\
\text { Banks } \\
\text { omitted } \\
\text { Robust } \\
\text { Std. } \\
\text { Errors }\end{array}$ \\
\hline CONSTANT & $\begin{array}{c}2.892 \\
(4.405)\end{array}$ & $\begin{array}{c}3.150 \\
(4.429)\end{array}$ & $\begin{array}{c}2.892 \\
(4.112)\end{array}$ & $\begin{array}{c}3.150 \\
(4.159)\end{array}$ & $\begin{array}{c}2.544 \\
(4.128)\end{array}$ & $\begin{array}{c}2.826 \\
(4.183)\end{array}$ \\
\hline ASSET & $\begin{array}{c}0.158 \\
(0.248)\end{array}$ & $\begin{array}{c}0.133 \\
(0.250)\end{array}$ & $\begin{array}{c}0.158 \\
(0.247)\end{array}$ & $\begin{array}{c}0.133 \\
(0.251)\end{array}$ & $\begin{array}{c}0.185 \\
(0.248)\end{array}$ & $\begin{array}{c}0.158 \\
(0.252)\end{array}$ \\
\hline TICAPRAT & $\begin{array}{c}0.117 \\
(0.139)\end{array}$ & $\begin{array}{c}0.108 \\
(0.140)\end{array}$ & $\begin{array}{c}0.117 \\
(0.125)\end{array}$ & $\begin{array}{c}0.108 \\
(0.126)\end{array}$ & $\begin{array}{c}0.041 \\
(0.163)\end{array}$ & $\begin{array}{c}0.038 \\
(0.167)\end{array}$ \\
\hline T2CAPRAT & $\begin{array}{c}0.023 \\
(0.244)\end{array}$ & $\begin{array}{l}-0.006 \\
(0.247)\end{array}$ & $\begin{array}{c}0.023 \\
(0.219)\end{array}$ & $\begin{array}{l}-0.006 \\
(0.222)\end{array}$ & $\begin{array}{l}-0.019 \\
(0.229)\end{array}$ & $\begin{array}{l}-0.043 \\
(0.233)\end{array}$ \\
\hline OTHER & $\begin{array}{c}0.943 * * \\
(0.272)\end{array}$ & $\begin{array}{c}0.926 * * \\
(0.273)\end{array}$ & $\begin{array}{c}0.943 * * \\
(0.235)\end{array}$ & $\begin{array}{c}0.926 * * \\
(0.231)\end{array}$ & $\begin{array}{c}0.969 * * \\
(0.227)\end{array}$ & $\begin{array}{c}0.948 * * \\
(0.224)\end{array}$ \\
\hline СОМР & $\begin{array}{l}-0.702 \\
(0.629)\end{array}$ & $\begin{array}{c}-0.666 \\
(0.631)\end{array}$ & $\begin{array}{l}-0.702 \\
(0.616)\end{array}$ & $\begin{array}{l}-0.666 \\
(0.616)\end{array}$ & $\begin{array}{l}-0.683 \\
(0.619)\end{array}$ & $\begin{array}{l}-0.649 \\
(0.621)\end{array}$ \\
\hline$U 2000$ & $\begin{array}{c}-0.246 \\
(0.158)\end{array}$ & $\begin{array}{c}-0.251 * \\
(0.159)\end{array}$ & $\begin{array}{c}-0.246^{* *} \\
(0.128)\end{array}$ & $\begin{array}{c}-0.251 * * \\
(0.129)\end{array}$ & $\begin{array}{c}-0.234^{*} \\
(0.129)\end{array}$ & $\begin{array}{c}-0.239 * \\
(0.130)\end{array}$ \\
\hline DIVIDEND & - & - & - & - & $\begin{array}{c}0.432 \\
(0.624)\end{array}$ & $\begin{array}{c}0.393 \\
(0.631)\end{array}$ \\
\hline $\begin{array}{l}\text { \# of } \\
\text { observations }\end{array}$ & 116 & 102 & 116 & 102 & 116 & 102 \\
\hline $\begin{array}{l}\text { Pseudo } \\
\text { R-squared }\end{array}$ & 0.344 & 0.314 & 0.344 & 0.314 & 0.348 & 0.317 \\
\hline $\begin{array}{l}\text { Log } \\
\text { likelihood }\end{array}$ & -35.973 & -35.567 & -35.973 & -35.567 & -35.785 & -35.412 \\
\hline
\end{tabular}


Table 7. Determinants of Total Deposit Growth

\begin{tabular}{|c|c|c|c|c|c|c|}
\hline Variable & $\begin{array}{l}\text { Market } \\
\text { Pricing }\end{array}$ & $\begin{array}{c}\text { Book } \\
\text { Values }\end{array}$ & $\begin{array}{l}\text { Market } \\
\text { Pricing }\end{array}$ & $\begin{array}{c}\text { Book } \\
\text { Values }\end{array}$ & $\begin{array}{l}\text { Market } \\
\text { Pricing }\end{array}$ & $\begin{array}{c}\text { Book } \\
\text { Values }\end{array}$ \\
\hline CONSTANT & $\begin{array}{l}0.310 * \\
(0.167)\end{array}$ & $\begin{array}{c}0.412 \\
(0.406)\end{array}$ & $\begin{array}{c}0.431 * * \\
(0.181)\end{array}$ & $\begin{array}{c}0.363 \\
(0.472)\end{array}$ & $\begin{array}{c}0.329 * * \\
(0.035)\end{array}$ & $\begin{array}{c}0.053 \\
(0.225)\end{array}$ \\
\hline$A S S E T$ & $\begin{array}{l}-0.003 \\
(0.009)\end{array}$ & $\begin{array}{c}0.008 \\
(0.012)\end{array}$ & $\begin{array}{l}-0.008 \\
(0.010)\end{array}$ & $\begin{array}{l}-0.002 \\
(0.013)\end{array}$ & $\begin{array}{c}0.007 \\
(0.009)\end{array}$ & $\begin{array}{c}0.009 \\
(0.027)\end{array}$ \\
\hline CAPRAT & $\begin{array}{c}0.021 * * \\
(0.005)\end{array}$ & $\begin{array}{c}0.014 \\
(0.011)\end{array}$ & $\begin{array}{c}0.031 * * \\
(0.005)\end{array}$ & $\begin{array}{c}0.025 * * \\
(0.012)\end{array}$ & - & - \\
\hline DIVIDEND & $\begin{array}{c}0.143 * * \\
(0.033)\end{array}$ & $\begin{array}{c}0.078 * * \\
(0.035)\end{array}$ & - & - & $\begin{array}{c}0.197 * * \\
(0.006)\end{array}$ & $\begin{array}{c}0.097 * * \\
(0.027)\end{array}$ \\
\hline OTHER & $\begin{array}{l}-0.002 \\
(0.004)\end{array}$ & $\begin{array}{c}0.019 \\
(0.056)\end{array}$ & $\begin{array}{l}-0.003 \\
(0.004)\end{array}$ & $\begin{array}{c}0.007 \\
(0.065)\end{array}$ & $\begin{array}{l}-0.000 \\
(0.037)\end{array}$ & $\begin{array}{l}-0.029 \\
(0.082)\end{array}$ \\
\hline$C O N$ & $\begin{array}{c}0.061 * * \\
(0.026)\end{array}$ & $\begin{array}{c}0.026 \\
(0.062)\end{array}$ & $\begin{array}{c}0.059 * * \\
(0.029)\end{array}$ & $\begin{array}{c}0.061 \\
(0.070)\end{array}$ & $\begin{array}{c}0.059 * * \\
(0.004)\end{array}$ & $\begin{array}{c}0.070 \\
(0.132)\end{array}$ \\
\hline$U 2001$ & $\begin{array}{c}0.014 * * \\
(0.006)\end{array}$ & $\begin{array}{c}0.021 \\
(0.017)\end{array}$ & $\begin{array}{c}0.016 * * \\
(0.007)\end{array}$ & $\begin{array}{c}0.011 \\
(0.020)\end{array}$ & $\begin{array}{c}0.012 \\
(0.029)\end{array}$ & $\begin{array}{c}0.035 \\
(0.145)\end{array}$ \\
\hline WEIGHT & $\begin{array}{l}-0.023 \\
(0.031)\end{array}$ & $\begin{array}{c}0.011 \\
(0.096)\end{array}$ & $\begin{array}{l}-0.031 \\
(0.034)\end{array}$ & $\begin{array}{c}0.020 \\
(0.112)\end{array}$ & $\begin{array}{c}-0.050 * * \\
(0.007)\end{array}$ & $\begin{array}{c}0.100 * * \\
(0.041)\end{array}$ \\
\hline $\begin{array}{l}\text { \# of } \\
\text { observations }\end{array}$ & 95 & 21 & 95 & 21 & 95 & 21 \\
\hline R-squared & 0.459 & 0.720 & 0.350 & 0.652 & 0.368 & 0.699 \\
\hline
\end{tabular}

Note: Results of second-stage estimation under ordinary least squares. Weighting variable from first-stage PROBIT estimation with full sample. See text and appendix for details. Figures in parentheses are standard errors. ** indicates statistical significance at 5\% confidence level. * indicates statistical significance at $10 \%$ confidence level. 
Table 8. Determinants of Time Deposit Growth

\begin{tabular}{|c|c|c|c|c|c|c|}
\hline Variable & $\begin{array}{l}\text { Market } \\
\text { Pricing }\end{array}$ & $\begin{array}{c}\text { Book } \\
\text { Values }\end{array}$ & $\begin{array}{l}\text { Market } \\
\text { Pricing }\end{array}$ & $\begin{array}{c}\text { Book } \\
\text { Values }\end{array}$ & $\begin{array}{l}\text { Market } \\
\text { Pricing }\end{array}$ & $\begin{array}{c}\text { Book } \\
\text { Values }\end{array}$ \\
\hline CONSTANT & $\begin{array}{c}0.747 * * \\
(0.193)\end{array}$ & $\begin{array}{c}0.814 \\
(0.592)\end{array}$ & $\begin{array}{c}0.865 * * \\
(0.205)\end{array}$ & $\begin{array}{c}0.786 \\
(0.621)\end{array}$ & $\begin{array}{c}0.768 * * \\
(0.217)\end{array}$ & $\begin{array}{c}0.498 \\
(0.749)\end{array}$ \\
\hline ASSET & $\begin{array}{c}-0.031 * * \\
(0.010)\end{array}$ & $\begin{array}{l}-0.015 \\
(0.017)\end{array}$ & $\begin{array}{c}-0.036 * * \\
(0.011)\end{array}$ & $\begin{array}{l}-0.021 \\
(0.017)\end{array}$ & $\begin{array}{l}-0.019 * \\
(0.011)\end{array}$ & $\begin{array}{l}-0.014 \\
(0.031)\end{array}$ \\
\hline CAPRAT & $\begin{array}{c}0.025 * * \\
(0.006)\end{array}$ & $\begin{array}{c}0.012 \\
(0.017)\end{array}$ & $\begin{array}{c}0.034 * * \\
(0.006)\end{array}$ & $\begin{array}{c}0.019 \\
(0.016)\end{array}$ & - & - \\
\hline DIVIDEND & $\begin{array}{c}0.139 * * \\
(0.038)\end{array}$ & $\begin{array}{c}0.045 \\
(0.051)\end{array}$ & - & - & $\begin{array}{c}0.201 * * \\
(0.039)\end{array}$ & $\begin{array}{c}0.062 \\
(0.083)\end{array}$ \\
\hline OTHER & $\begin{array}{l}-0.001 \\
(0.004)\end{array}$ & $\begin{array}{c}0.007 \\
(0.082)\end{array}$ & $\begin{array}{l}-0.002 \\
(0.005)\end{array}$ & $\begin{array}{l}-0.000 \\
(0.086)\end{array}$ & $\begin{array}{c}0.001 \\
(0.005)\end{array}$ & $\begin{array}{l}-0.035 \\
(0.107)\end{array}$ \\
\hline СОМР & $\begin{array}{c}0.038 \\
(0.030)\end{array}$ & $\begin{array}{l}-0.006 \\
(0.090)\end{array}$ & $\begin{array}{c}0.036 \\
(0.033)\end{array}$ & $\begin{array}{c}0.015 \\
(0.091)\end{array}$ & $\begin{array}{c}0.036 \\
(0.034)\end{array}$ & $\begin{array}{c}0.034 \\
(0.132)\end{array}$ \\
\hline U2001 & $\begin{array}{c}0.004 \\
(0.007)\end{array}$ & $\begin{array}{c}0.019 \\
(0.025)\end{array}$ & $\begin{array}{c}0.007 \\
(0.007)\end{array}$ & $\begin{array}{c}0.013 \\
(0.026)\end{array}$ & $\begin{array}{c}0.003 \\
(0.008)\end{array}$ & $\begin{array}{c}0.031 \\
(0.035)\end{array}$ \\
\hline WEIGHT & $\begin{array}{l}-0.050 \\
(0.036)\end{array}$ & $\begin{array}{c}0.029 \\
(0.140)\end{array}$ & $\begin{array}{l}-0.057 \\
(0.039)\end{array}$ & $\begin{array}{c}0.034 \\
(0.147)\end{array}$ & $\begin{array}{c}-0.081 * * \\
(0.040)\end{array}$ & $\begin{array}{c}0.108 \\
(0.167)\end{array}$ \\
\hline $\begin{array}{l}\text { \# of } \\
\text { observations }\end{array}$ & 95 & 21 & 95 & 21 & 95 & 21 \\
\hline R-squared & 0.424 & 0.423 & 0.339 & 0.397 & 0.325 & 0.405 \\
\hline
\end{tabular}

Note: Results of second-stage estimation under ordinary least squares. Weighting variable from first-stage PROBIT estimation with full sample. See text and appendix for details. Figures in parentheses are standard errors. ** indicates statistical significance at 5\% confidence level. * indicates statistical significance at $10 \%$ confidence level. 


\section{References}

Billett, Matthew T., Jon A. Garfinkel, and Edward S. O’Neal, “The Cost of Market versus Regulatory Discipline in Banking," Journal of Financial Economics, 48, 333-358.

Flannery, Mark J. and Sorin M. Sorescu, 1996, "Evidence of Bank Market Discipline in Subordinated Debenture Yields," Journal of Finance 51, 1347-1377.

Gilbert, R. Alton and Mark D. Vaughan, 2001, "Do Depositors Care About Enforcement Actions?,” Journal of Economics and Business, 53, 283-311.

Goldberg, Lawrence G., and Sylvia C. Hudgins, 2002, "Depositor Discipline and Changing Strategies for Regulating Thrift Institutions," Journal of Financial Economics, 63, 263-274.

Gunther, Jeffery W., and Robert R. Moore, 2000, "Financial Statements and Reality: Do Troubled Banks Tell All?" Federal Reserve Bank of Dallas Economic and Financial Review, Third Quarter, 30-35.

Healy, P. and K. Palepu, 2001, "A Review of the Empirical Disclosure Literature," Journal of Accounting and Economics, 31, 405-440.

Jordan, John S., 2000, “Depositor Discipline at Failing Banks,” New England Economic Review, March/April, 15-28.

Jordan, John S., Joe Peek, and Eric Rosengren, 2000, “The Impact of Greater bank Disclosure Amidst a Banking Crisis," Journal of Financial Intermediation 9, 298-319.

Lee, L. F., 1976, "Estimation of Limited Dependent Variable Models by Two-Stage Methods, Ph.D. dissertation, University of Rochester.

Maddala, G.S., 1983, Limited-Dependent and Qualitative Variables in Economics, Cambridge University Press, New York.

Morgan, Donald P. and Kevin J. Stiroh, 2001, "Market Discipline of Banks: The Asset Test," Journal of Financial Services Research 20, 195-208.

Spiegel, Mark M. and Nobuyoshi Yamori, 2004, "The Evolution of Bank Resolution Policies in Japan: Evidence from Market Equity Values," Journal of Financial Research, 27(1), Spring, 115-132.

Spiegel, Mark M. and Nobuyoshi Yamori, 2004, "Determinants of Voluntary Bank Disclosure: Evidence from Japanese Shinkin Banks," forthcoming in Hutchison and Westermann, eds., Addressing Japan's Macroeconomic Crisis, MIT Press, Cambridge. 